\title{
Molecular Evidence of Anticancer Activity of Camel Milk Combined with Camel Urine
}

\author{
Gupta I ${ }^{1}$, Shanmuganathan $\mathrm{S}^{2}$, Al-Abri $\mathrm{H}^{2}$ and \\ Ouhtit A ${ }^{3 *}$ \\ ${ }^{1}$ College of Medicine, QU Health, Qatar University, Doha, \\ Qatar \\ ${ }^{2}$ Department of Genetics, College of Medicine and Health \\ Sciences, Sultan Qaboos University, Muscat, Sultanate of \\ Oman \\ ${ }^{3}$ Department of Biological and Environmental Sciences, \\ College of Arts and Sciences, Qatar University, Doha, \\ Qatar \\ *Correspondling author: Ouhtit A, Department of \\ Biological and Environmental Sciences, College of Arts \\ and Sciences, Qatar University, Doha, Qatar
}

Received: J une 01, 2021; Accepted: August 03, 2021; Published: August 10, 2021

\begin{abstract}
Camel Milk (CM) and Camel Urine (CU) is a traditional practice in the Middle East and other countries as an alternative treatment against cancer. We hypothesized that a combination of $\mathrm{CM}$ and $\mathrm{CU}(\mathrm{CM}+\mathrm{CU})$, used at bioavailable concentrations, will result in cancer cell apoptosis without toxic effect on normal epithelial cell lines. Pursuant to this goal, we investigated $\mathrm{CM}+\mathrm{CU}$ effect on breast $(\mathrm{BC})$ and Prostate Cancer (PC) cell lines and examined its underlying mechanisms of action in-vitro. The highly metastatic BC (MDA-MB-231) and PC (PC3) cells as well as the non-tumorigenic epithelial cell line (MCF-10A) were treated with Filtered Camel Milk (FCM) and Virgin Camel Urine (VCU), both individually and in combination at bioavailable concentration levels. Although FCM and VCU were effective individually, the FCM+VCU combination significantly suppressed BC and PC cell proliferation (>80\%), and surprisingly induced $100 \%$ cell death. In contrast, no deleterious effects were observed in MCF-10A control cells. More interestingly, the FCM+VCU combination upregulated Bax and downregulated expression of $\mathrm{Bcl}-2$ and hypo-phosphorylated $\mathrm{Rb}$ expression in both $\mathrm{BC}$ and $\mathrm{PC}$ cell lines. In conclusion, this is the first study providing evidence of in-vitro chemo-preventive synergistic effect of $\mathrm{FCM}+\mathrm{VCU}$ combination against $\mathrm{BC}$ and $\mathrm{PC}$ cells, supporting its anticancer property.
\end{abstract}

Keywords: Camel milk; Camel urine; Breast cancer; Prostate cancer; Cell proliferation; Apoptosis

\section{Abbreviations}

Bax: BCL-2 Associated X; Apoptosis Regulator; BC: Breast Cancer; Bcl-2: B-cell Lymphoma-2; CAM: Complementary Alternative Medicine; CLED: Cystine-Lactose-Electrolyte-Deficient Agar; CM: Camel Milk; CU: Camel Urine; DMEM: Dulbecco's Modified Eagle's Medium; ER: Estrogen Receptor; FBS: Fetal Bovine Serum; FCM: Filtered Camel Milk; LCU: Lactating Camel Urine; PC: Prostate Cancer; PCU: Pregnant Camel Urine; PR: Progesterone Receptor; Rb: Retinoblastoma; TNBC: Triple-Negative Breast Cancer; VCU: Virgin Camel Urine; WAP: Whey Associated Protein

\section{Introduction}

Breast Cancer (BC) is to the most common cancer in women worldwide reaching a rate of $25 \%$ of cancer cases [1]. While, BC is the most frequent cause of cancer-related mortality $(\sim 14 \%)$ in developing countries, it is the second cause of death in developed countries ( 15\%) [1]. A number of known risk factors include both environmental and genetic players associated with the onset of $\mathrm{BC}$ [2]. $\mathrm{BC}$ is a highly heterogeneous disease and gene expression profiling classified BC into four molecular subtypes: Luminal (A and B), HER2, basal-like and normal-like using hierarchical cluster analysis [3]. From the four subtypes, Triple Negative BC (TNBC) tumour subtype is highly aggressive as it lacks or has a relatively lower expression of the three receptors, Estrogen (ER), Progesterone (PR) and HER-2/ neu. TNBC is considered as an advanced stage, a higher histologic grade, and significantly higher metastatic rates [4-7].

On the other hand, Prostate Cancer (PC) is the most common cancer in men, being the third-leading cause of cancer death in men [1]. The main risk factors associated with the onset of PC include age, race as well as family history [8]. Similar to BC, PC is morphologically heterogeneous [9]. Although, with advancement in diagnosis, they remain asymptomatic until locally advanced stages or the establishment of metastatic tumor [9].

While, systemic treatment for BC includes cytotoxic, hormonal, and immunotherapeutic agents, for TNBC, cytotoxic chemotherapy is the treatment modality of choice [6,10-12]. However surgery, radiotherapy and chemotherapy remain the curative treatment strategies for PC [13]. Although, these treatment modalities appear effective during the initial stages of therapy in around $90 \%$ of primary, and approximately half of metastatic cancer cases [14], resistance to therapy occurs leading to treatment failure and mortality in more than half of the patients with advanced/metastatic disease [14]. Hence, it is essential to develop an alternative to conventional therapy, using natural phytochemicals present in foods such as vegetables, fruits, spices and plant roots which pose to be less harmful and more efficient in preventing or eradicating tumors [15-17]. Recent studies have shown anti-oxidant, anti-inflammatory, anti-proliferative and proapoptotic effects of various phytochemicals $[15,16,18,19]$, suggesting their ability to block the growth of several types of tumors of the blood, skin, brain, colon, ovaries, breast, prostate and the pancreas $[20,21]$.

Research in Complementary Alternative Medicine (CAM) has been vital for finding natural bioactive compounds as a complementary or alternative cancer treatment modality. For several 
decades, combination of Camel Milk (CM) and Camel Urine (CU) have been practiced as a traditional treatment in the Arab countries for various ailments, including cancer [22,23]. Camel (Camelus dromedarius) products, including camel milk or urine have been used for the treatment of several diseases, including chronic hepatitis [24], hepatitis C [25,26], peptic ulcers [27] as well as cancer [28]. Moreover, while, camel milk possesses anti-cancer, anti-platelet, antithrombotic, anti- bacterial as well as anti-viral properties [29-31], camel urine was shown to have anti-platelet, anti-bacterial and antifungal properties [32-34]. Importantly, virgin camel urine showed the highest degree of inhibition at the activity level, followed by lactating and pregnant camel urines [35].

To our knowledge, no study has tested the traditional combination of Camel Milk (CM) and Urine (CU) for its effectiveness as an anticancer effect. The findings described above prompted us to test the hypothesis that $\mathrm{CM}+\mathrm{CU}$ has a synergistic anti-proliferative effect on breast and prostate tumours.

\section{Materials and Methods}

\section{Cell culture}

The metastatic BC (MDA-MB-231, ATCC ${ }^{*}$ HTB-26 ${ }^{\mathrm{TM}}$ ) and PC cell lines (PC3, ATCC CRL-1435 ${ }^{\mathrm{TM}}$ ) derived from female and a grade IV adenocarcinoma male, respectively, and the non-tumorigenic epithelial cell line, MCF10-A (ATCC ${ }^{\circ}$ CRL-10317 ${ }^{\mathrm{TM}}$ ) derived from a female were purchased from American Type Culture Collection (ATCC). The MCF10-A cell line was used as a control normal cell line. Cells were grown and expanded in Dulbecco's Modified Eagle Medium (DMEM; Gibco, Life Technologies) supplemented with $10 \%$ heat-inactivated fetal bovine serum (FBS; Invitrogen, Life Technologies), 1\% penicillin/streptomycin antibiotics (Invitrogen, Life Technologies) at $37^{\circ} \mathrm{C}$ and $5 \% \mathrm{CO}_{2}$ levels.

\section{Collection and sterility of camel milk and camel urine samples}

Camel Milk (CM) samples were kindly provided by $\mathrm{Mr}$. Mohammed Alnaaimi from Hafeet, Al Buraimi Governorate, the Sultanate of Oman. Collection of samples was performed with a careful care to avoid any contamination from the animal itself (skin or hair) or from the outside environment during the collection procedure. In camel milk, $a$-lactalbumin is the vital component of whey protein; previous study has indicated presence of total solids (12\%), protein (3\%), fat (4\%), lactose, (4\%), ash (1\%), $4.4 \%$ lactose and acidity (0.1\%) with a $\mathrm{pH}$ of $6.5[36,37]$. Further, gas liquid chromatography analysis of camel milk fat revealed presence of palmitic (27\%), oleic (25\%), myristic (11\%), and palmitoleic (11\%) acids (36).

Camel urine samples were kindly provided by Mr. Ibrahim AlBusaidy (College of Agricultural and Marine Sciences, Sultan Qaboos University, Oman) from Dakhlia region, the Sultanate of Oman. Mid-stream urine from Virgin Camels (VCU) was collected in sterile culture tubes. Upon receiving these samples, they were frozen at $-80^{\circ} \mathrm{C}$. Camel urine analysis by GC-MS identified metabolic products including benzene propanoic acid derivatives, fatty acid derivatives, amino acid derivatives, sugars, prostaglandins and canavanine [38].

According to preliminary studies in our laboratory on $\mathrm{CM}$ sterilization, CM was filtered through $0.22 \mu \mathrm{m}$ filter producing a clear Filtered Camel Milk (FCM). Prior to use in cell culture treatment, the sterility of both, Filtered CM (FCM) and VCU were tested by culturing each sample on Blood agar and CLED media at $37^{\circ} \mathrm{C}$ for 24 hours in our Microbiology laboratory within the Department of Microbiology at Sultan Qaboos University Hospital, Sultanate of Oman. After 24 hours of incubation, these cultures were examined to check for the presence of bacterial growth. Both VCU and FCM samples were sterile.

\section{Cell proliferation assay in the presence of Filtered Camel Milk (FCU) and Virgin Camel Urine (VCU)}

MDA-MB-231, PC3 and MCF-10A cell lines were plated on clear bottom black 96 well plates (2000 cells/well) and cultured in DMEM supplemented with $10 \%$ fetal bovine serum (FBS) and $1 \%$ penicillin and streptomycin $(0.1 \mathrm{ml} /$ well $)$.

FCM and VCU were dissolved in DMEM media. For treatment of cells, FCM dilutions were prepared in range of concentrations $(100 \mu \mathrm{l} / \mathrm{ml}, 200 \mu \mathrm{l} / \mathrm{ml}, 300 \mu \mathrm{l} / \mathrm{ml}, 400 \mu \mathrm{l} / \mathrm{ml}, 500 \mu \mathrm{l} / \mathrm{ml}, 600 \mu \mathrm{l} / \mathrm{ml}$ and $700 \mu \mathrm{l} / \mathrm{ml}$ ) and were treated individually for 48 hours. On the other hand, VCM dilutions were prepared in range of concentrations $(50 \mu \mathrm{l} /$ $\mathrm{ml}, 100 \mu \mathrm{l} / \mathrm{ml}, 150 \mu \mathrm{l} / \mathrm{ml}, 200 \mu \mathrm{l} / \mathrm{ml}, 250 \mu \mathrm{l} / \mathrm{ml}, 300 \mu \mathrm{l} / \mathrm{ml}$ and $350 \mu \mathrm{l} /$ $\mathrm{ml}$ ). Control (untreated cells) received $100 \mu \mathrm{L}$ of media. A combined treatment of FCM (Filtered Camel Milk) and VCU (Virgin Camel Urine) was prepared at various concentrations for both the cell lines and treated for a period of 48 hours. MDA-MB-231 cells were treated with a combination of FCM:VCU at concentrations of $(400 \mu \mathrm{l} /$ $\mathrm{ml}: 250 \mu \mathrm{l} / \mathrm{ml})$ and $(450 \mu \mathrm{l} / \mathrm{ml}: 200 \mu \mathrm{l} / \mathrm{ml})$, while PC3 cells were treated at concentrations of $(600 \mu \mathrm{l} / \mathrm{ml}: 300 \mu \mathrm{l} / \mathrm{ml})$ and $(700 \mu \mathrm{l} / \mathrm{ml}: 200 \mu \mathrm{l} / \mathrm{ml})$ for 48 hours. MCF-10A cells were treated with a combination of FCM:VCU at concentrations of $400 \mu \mathrm{l} / \mathrm{ml}: 250 \mu \mathrm{l} / \mathrm{ml}, 450 \mu \mathrm{l} / \mathrm{ml}: 200 \mu \mathrm{l} /$ $\mathrm{ml}, 600 \mu \mathrm{l} / \mathrm{ml}: 300 \mu \mathrm{l} / \mathrm{ml}$ and $700 \mu \mathrm{l} / \mathrm{ml}: 200 \mu \mathrm{l} / \mathrm{ml}$ for 48 hours.

The suppression of cell proliferation was determined after 48 hours using the Alamar Blue cell proliferation assay (Alamar Biosciences, Sacramento, CA), according to the manufacturer's specifications, as previously described by our group [17]. Post-incubation with the Alamar Blue dye for 4 hours, shift in fluorescence was measured at a wavelength of $570 \mathrm{~nm}$ (excitation) and $600 \mathrm{~nm}$ (emission) in a Fluorometer (LabSystems Fluoreskan-II). Relative cell proliferation is expressed based on the fluorescence of drug-treated cells (MDAMB-231 and PC3) in comparison with that of control cells, MCF10A. MCF-10A were used in all experiments as negative controls.

\section{Trypan blue cell viability assay}

To determine cell viability assay, the Trypan blue assay was performed. Post-treatment for 48 hours, cells were detached by trypsinization and the number of viable cells was counted using a Trypan blue stain reagent. The viability of the control (untreated cells) was regarded as $100 \%$.

\section{Western blot analysis}

To understand the underlying molecular pathways including apoptosis and cell-cycle regulation, we analyzed the expression levels of proteins by Western blot analysis as previously described by our group [17]. Both, MDA-MB-231 and PC3 cells were treated with the same concentrations of the above-described FCM and VCU for 48 hours. Total cell lysates were collected using RIPA buffer (Santa Cruz, CA) and equal amounts $(30 \mu \mathrm{g})$ of total cell extracts were resolved on $10 \%$ polyacrylamide gels and electroblotted onto 
$\mathbf{a}$

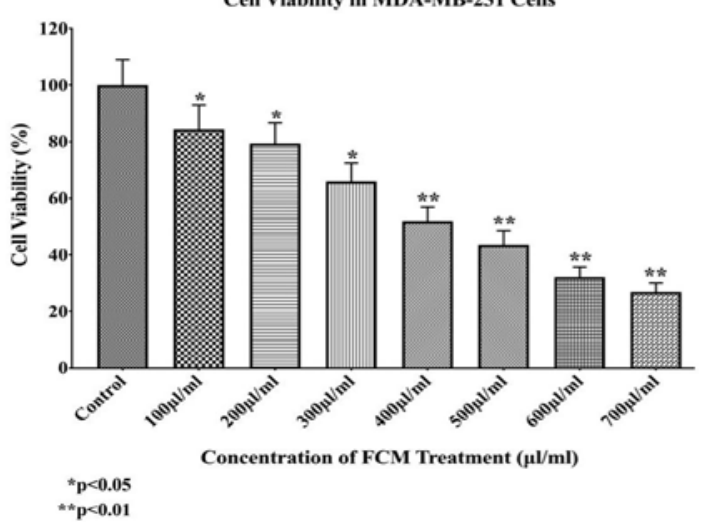

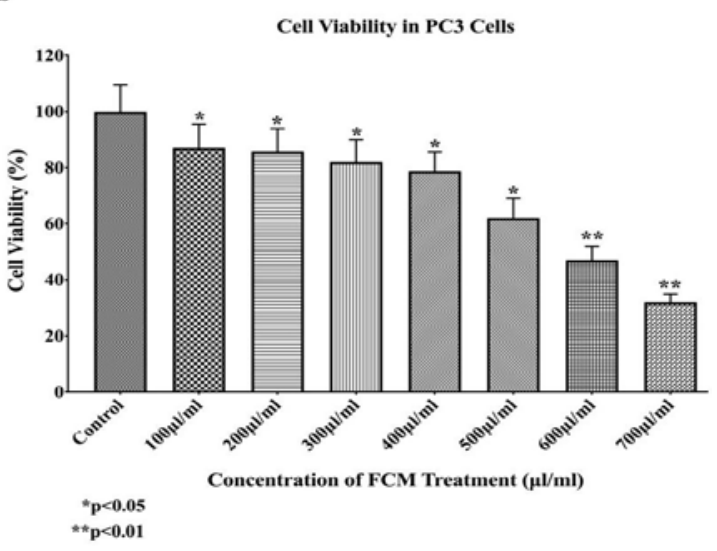

Figure 1: Effect of Filtered Camel Milk (FCM) treatment at varying concentration after a period of 48 hours. a) Mean cell viability of breast cancer cells (MDAMB-231) after treatment with FCM for a period of 48 hours. b) Mean number of Prostate Cancer cells (PC3) after treatment with FCM for a period of 48 hours. The data are expressed as mean \pm standard error of mean and the experiments were done in triplicates $(p<0.05, p<0.01)$.

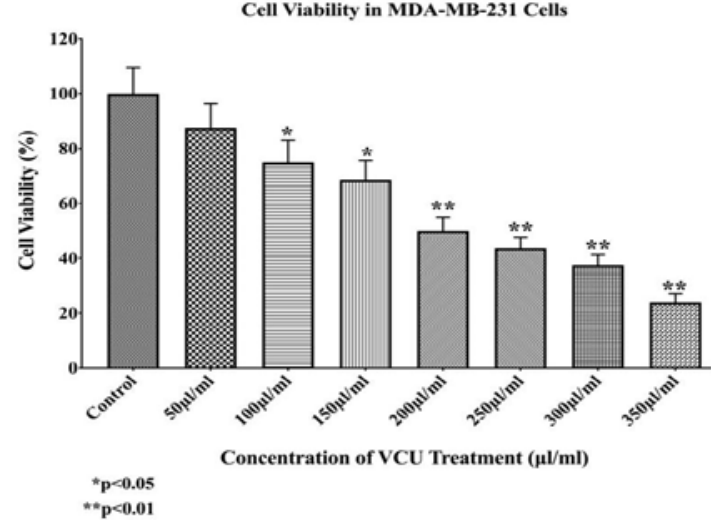

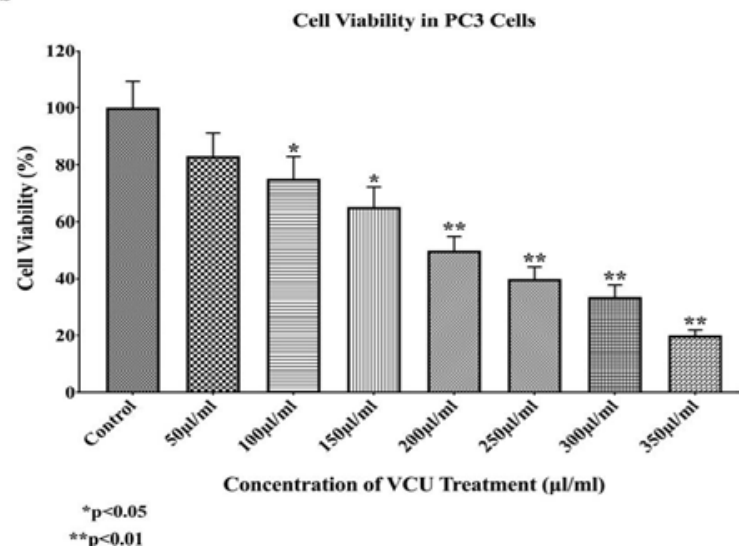

Figure 2: Effect of Virgin Camel Urine (VCU) treatment at varying concentration after a period of 48 hours. a) Mean cell viability of breast cancer cells (MDAMB-231) after treatment with VCU for a period of 48 hours. b) Mean number of prostate cancer cells (PC3) after treatment with VCU for a period of 48 hours. The data are expressed as mean \pm standard error of mean and the experiments were done in triplicates $(p<0.05, p<0.01)$.

nitrocellulose membranes. The nitrocellulose membranes were probed with a number of primary antibodies as follows: anti-mouse Bax (1:200 dilution, Santa Cruz Biotechnology, CA), anti-mouse Bcl2 (1:200 dilution, Santa Cruz Biotechnology, CA), and anti-rabbit Rb (1:200 dilution, Santa Cruz Biotechnology, CA). Anti-rabbit $\beta$-actin antibody (1:500 dilution, Santa Cruz Biotechnology, CA) was used to ensure equal loading of protein samples. ECL Western blotting substrate was used to analyze immunoreactivity as recommended by the manufacturer (Pierce Biotechnology) and blots were imaged using the iBright ${ }^{\mathrm{TM}}$ CL1000 imaging system (Thermo Fisher Scientific, Waltham, MA, USA).

Relative quantification of protein expression was obtained by analyzing captured images using ImageJ software as described by our group [39].

\section{Statistical analysis}

Data are presented as Mean \pm SEM (Standared Error of Mean) of at least triplicates or replicates from three experiments and the data were analyzed statistically using Student's $t$-test using GraphPad
Prism software (version 8.4.3) and differences with $\mathrm{p}<0.05$ were considered significant.

\section{Results}

\section{Effects of Filtered Camel Milk (FCM) and Virgin Camel Urine (VCU) on cell proliferation and apoptosis}

In our laboratory, a preliminary study comparing the effect of $\mathrm{CU}$ from virgin, lactating and pregnant camels demonstrated that virgin $\mathrm{CU}$ showed the highest degree of inhibition of cancer cell proliferation than the CU from pregnant and lactating camels (Supplementary Figure 1).

Using Alamar-Blue cell proliferation assay, several combinations of FCM and VCU were examined for their effects on cell proliferation and cell death, both individually and in combination. Our results revealed that the half maximal Inhibitory Constant $\left(\mathrm{IC}_{50}\right)$ of FCM for MDA-MB-231 and PC3 cells was $400 \mu \mathrm{l} / \mathrm{ml}$ and $600 \mu \mathrm{l} / \mathrm{ml}$, respectively. Moreover, the $\mathrm{IC}_{50}$ of VCU for both MDA-MB-231 and PC3 cells was $200 \mu \mathrm{l} / \mathrm{ml}$. Based on these preliminary results, the combination of FCM and VCU was tested. Using these established 


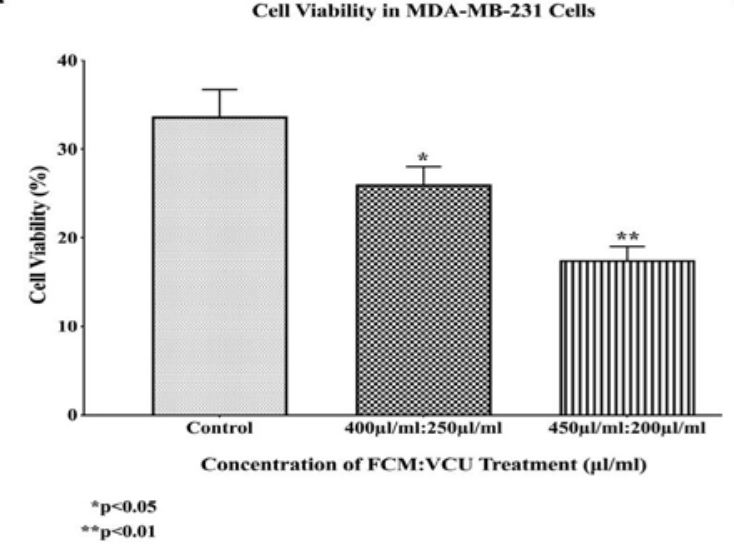

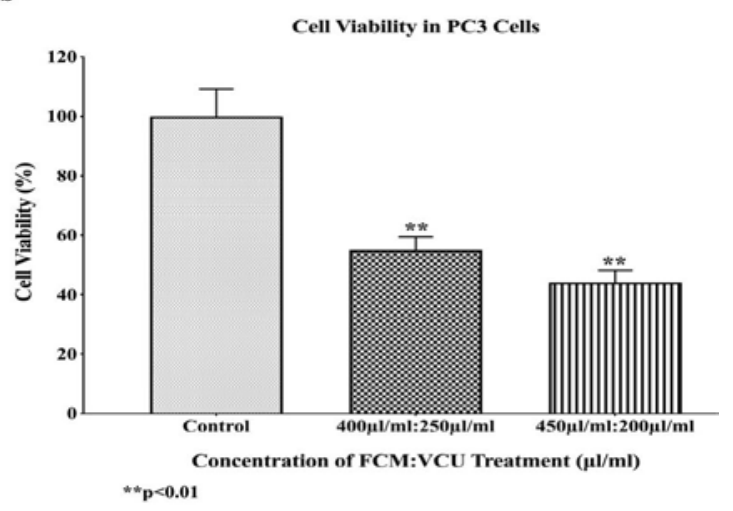

Figure 3: Effect of combination of Filtered Camel Milk (FCM) and Virgin Camel Urine (VCU) treatment at varying concentration on cancer cells in response to after a period of 48 hours. a) Mean cell viability of breast cancer cells (MDA-MB-231) after treatment with FCM and VCU for a period of 48 hours. b) Mean number of Prostate Cancer cells (PC3) after treatment with FCM and VCU for a period of 48 hours. The data are expressed as mean \pm standard error of mean and the experiments were done in triplicates $(p<0.01)$.

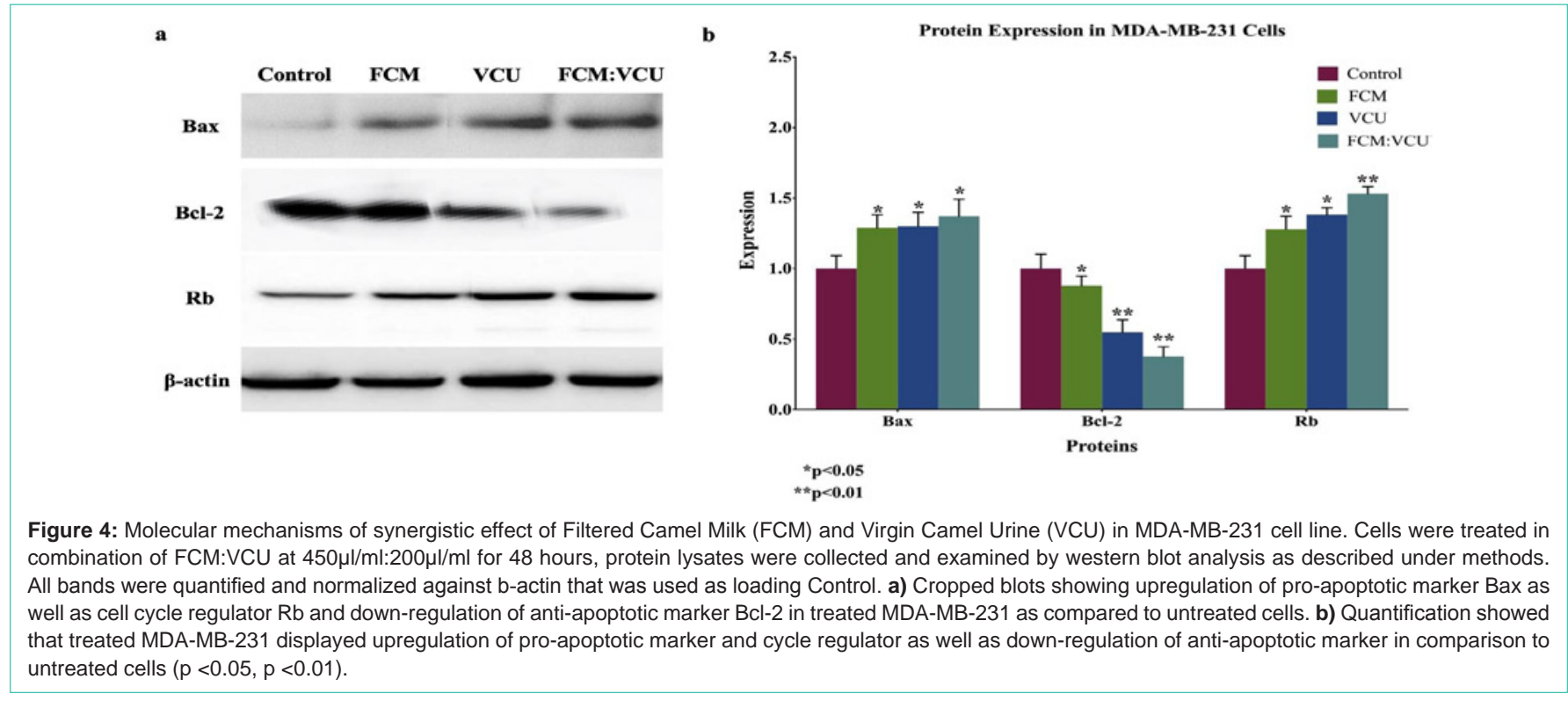

individual concentrations for the combination treatment. In this assay, treatment of MCF-10A with the combination was used as a control and was considered as $100 \%$ in comparison to cancer cells treated with FCM and VCU. A moderate effect was observed on MDA-MB-231 and PC3 cell proliferation by individual treatments at day 1 (Figure 1 and 2).

On the other hand, our results showed that synergistic effect of $\mathrm{FCM}+\mathrm{VCU}$ resulted in a significant reduction in cell proliferation in both MDA-MB-231 (Figure 3a) and PC3 cells (Figure 3b) as compared to individual treatments.

Furthermore, in accordance with our cell proliferation data, Trypan-Blue assay showed that MDA-MB-231 cells exhibited a smooth epithelial cell pattern with prominent nuclei on day 0 of the experiment (before treatment). In contrast, in MDA-MB-231 and PC3 cells. combination treatment (FCM+VCU), resulted in loss of cell-cell contact and cells detached from the surface of the tissue culture dish, suggesting that a decrease in cell proliferation might be the result of increased cell death.

\section{Molecular mechanisms of action of in the FCM+VCU combination}

Based on the above data, we further explored the levels of protein expression by Western blot in response to the combination FCM+VCU in both MDA-MB-231 and PC3 cells. While, the expression levels of the pro-apoptotic protein Bax was significantly increased, a significant decrease in the expression of the anti-apoptotic proteins Bcl-2 was detected in both cell lines (Figure 4). Moreover, expression of the cell cycle regulator Rb was increased (Figure 4).

Taken together, these data support our hypothesis that the combination FCM+VCU might have inhibited cell growth via induction of RB expression, and induced apoptosis through an increase in the $\mathrm{Bax} / \mathrm{Bcl}-2$ ratio. 


\section{Discussion}

Complementary Alternative Medicine (CAM) is effective in inhibiting proliferation of a variety of cancer cells $[15,18,19,21]$. Camel products including, Camel milk and urine have been used traditionally in CAM treatment, especially in the Islamic world [40] due to their anti-cancer activity, including breast, lung as well as nasopharyngeal cancers $[28,29,41]$. In the present study both FCM and VCU were tested, individually and in combination, on the proliferation of metastatic MDA-MB-231 BC cells and PC3 PC cells. We tested the hypothesis that $\mathrm{FCM}+\mathrm{VCU}$ combination can inhibit both $\mathrm{BC}$ and $\mathrm{PC}$ cell proliferation. To our knowledge, the present study is the first to demonstrate a chemo-preventive effect of the combination of FCM+VCU using in-vitro model.

Initially, we have demonstrated that FCM, individually, induced apoptosis in both MDA-MB-231 and PC3 cells. A number of studies have well characterized the anticancer properties of FCM and its components. In fact, Nukumi et al. (2006) showed that the milk bioactive compound, Whey Acidic Protein (WAP), inhibited tumorigenesis and invasion of human BC cells MCF-7 and MDAMB-453 [42]. In another study by the same group, WAP inhibited cell invasion via degradation of the basement membrane component, laminin matrigel [42]. Lactoferrin, another bioactive component in milk, has shown anti-cancer and anti-microbial activities [43-45]. In fact, lactoferrin blocked cell proliferation by inhibiting cytochrome P450 1a1 gene expression [46]. On the other hand, casein binds to a-lactalbumin to form a complex with oleic acid resulting in apoptosis of various cancer cells $[47,48]$. Interestingly, a recent study reported that FCM induced its cytotoxic effect on human colorectal and BC cells via autophagy [49]. More interestingly, FCM and its exosomes (membrane vesicles with a diameter of $40-100 \mathrm{~nm}$, secreted by cells and found in milk) reduced breast tumor progression via induction of cell death, activation of immune responses as well as suppression of oxidative stress, inflammation, angiogenesis, and metastasis [50].

Likewise, a number of studies have already characterized the anticancer properties of Camel Urine (CU). In fact, CU inhibited cellular growth of various tumor cells, including hepatocellular, colon, glioma, and lung cancer cells $[28,35,49,51,52]$. In the present study, Virgin CU (VCU) inhibited proliferation of both MDA-MB-231 and PC3 cells by $40-60 \%$. Comparable to our data, a recent study showed that $\mathrm{CU}$ inhibited cancer cell proliferation at a concentration greater than $100 \mu \mathrm{l} / \mathrm{ml}$ [28]. CU encompasses several bioactive metabolites, including canavanine, erythritol, benzenepropanoic acid and melibiose [53], and Canavanine, a potent L-arginine antimetabolite, has a powerful anti-cancer activity in various human cancer cells [54-56] Moreover, Al-Yousef N et al. [52] showed that CU inhibited cell proliferation and triggered apoptosis of breast carcinomas and medullo-blastomas cells at a rate higher than $80 \%$. Romli et al. (2017) have demonstrated, both in-vitro and in-vivo, that CU significantly suppressed growth and metastasis of the mouse $4 \mathrm{~T} 1 \mathrm{BC}$ cells, by inducing cell death through DNA fragmentation and regulation of inflammation-related genes, as well as by downregulation of various angiogenesis-related proteins [28].

The results from the studies described above strongly support our hypothesis that the combination FCM+VCU significantly inhibited (up to $80 \%$ ) proliferation of the highly metastatic MDA-MB-231 cells and PC3 cells, as compared to the individual treatments. Interestingly, no reduction in proliferation rate was observed in the control MCF$10 \mathrm{~A}$ cells treated with the combination.

To further confirm the induction of apoptosis, changes in the expression of the apoptotic and anti-apoptotic proteins, Bax and Bcl-2, were investigated. Western blot analysis indicated that the treatment of the MDA-MB-231 BC cells with the combination $\mathrm{FCM}+\mathrm{VCU}$, not only played a significant role in apoptosis (upregulation of Bax and down-regulation of Bcl-2), but also in other cell regulatory pathways (up-regulation of $\mathrm{Rb}$ ) as compared to individual treatments. Our molecular results are supported by the findings from a previous study by Delou et al. (2016) showing that increased $\mathrm{Rb}$ levels can activate Bax and reduce Bcl-2 levels, resulting in apoptosis [57]. Other studies have already characterized the same molecular pathway (Rb/bax/Bcl-2)-regulated apoptosis in CM-treated BC cells $[29,41,58]$. Likewise, CU-treated cells triggered apoptosis via the intrinsic pathway (elevated Bax and reduced Bcl-2 levels) along with the down-regulation of cancer-promoting proteins including survivin, B-catenin, and cyclin D1, and the upregulation of cyclindependent kinase inhibitor p21 [52].

\section{Conclusion}

Despite the recent advances in conventional diagnostic and therapeutic technologies for $\mathrm{BC}$ and $\mathrm{PC}$ management, treatment of $\mathrm{BC}$ and $\mathrm{PC}$ remains challenging, particularly in triple-negative $\mathrm{BC}$ and metastatic PC. CAM appears to gain more interest due its safety and efficacy amid lack of sufficient scientific evidence. Nevertheless, our findings provide the first evidence supporting our hypothesis that of the traditional FCM+VCU combination can suppress BC and PC cell proliferation via induction of apoptosis regulated by $\mathrm{Rb} / \mathrm{Bax} /$ $\mathrm{Bcl}-2$ pathway. More interestingly, ongoing in vivo studies aim to validate the efficacy of the FCM+VCU combination is suppressing progression of both breast and prostate tumours.

\section{Funding}

This research was funded by Qatar University Internal grant number: QUST-1-CAS2019-22.

\section{References}

1. Ferlay J, Colombet M, Soerjomataram I, Mathers C, Parkin DM, Piñeros M, et al. Estimating the global cancer incidence and mortality in 2018: GLOBOCAN sources and methods. Int J Cancer. 2019; 144: 1941-1953.

2. Gupta I, Burney I, Al-Moundhri MS, Tamimi Y. Molecular genetics complexity impeding research progress in breast and ovarian cancers. Mol Clin Oncol. 2017; 7: 3-14.

3. Perou CM, Sørlie T, Eisen MB, van de Rijn M, Jeffrey SS, Rees CA, et al. Molecular portraits of human breast tumours. Nature. 2000; 406: 747-752.

4. Stockmans G, Deraedt K, Wildiers H, Moerman P, Paridaens R. Triplenegative breast cancer. Current Opinion in Oncology. 2008; 20: 614-620.

5. Thike AA, Cheok PY, Jara-Lazaro AR, Tan B, Tan P, Tan PH. Triple-negative breast cancer: clinicopathological characteristics and relationship with basallike breast cancer. Modern Pathology. 2010; 23: 123-133.

6. Yadav BS, Chanana $\mathrm{P}$, Jhamb $\mathrm{S}$. Biomarkers in triple negative breast cancer: A review. World J Clin Oncol. 2015; 6: 252-263.

7. Irvin WJ, Carey LA. What is triple-negative breast cancer? European Journal of Cancer. 2008; 44: 2799-2805.

8. Leitzmann MF, Rohrmann S. Risk factors for the onset of prostatic cancer: age, location, and behavioral correlates. Clin Epidemiol. 2012; 4: 1-11. 
9. Smith-Palmer J, Takizawa C, Valentine W. Literature review of the burden of prostate cancer in Germany, France, the United Kingdom and Canada. BMC Urology. 2019; 19: 19.

10. Liedtke C, Mazouni C, Hess KR, André F, Tordai A, Mejia JA, et al. Response to Neoadjuvant Therapy and Long-Term Survival in Patients With TripleNegative Breast Cancer. Journal of Clinical Oncology. 2008; 26: 1275-1281.

11. Kassam F, Enright K, Dent R, Dranitsaris G, Myers J, Flynn C, et al. Survival Outcomes for Patients with Metastatic Triple-Negative Breast Cancer: Implications for Clinical Practice and Trial Design. Clinical Breast Cancer. 2009; 9: 29-33.

12. Park JH, Ahn J-H, Kim S-B. How shall we treat early triple-negative breas cancer (TNBC): from the current standard to upcoming immuno-molecular strategies. ESMO Open. 2018; 3: e000357.

13. Litwin MS, Tan HJ. The Diagnosis and Treatment of Prostate Cancer: A Review. Jama. 2017; 317: 2532-2542.

14. Gonzalez-Angulo AM, Morales-Vasquez F, Hortobagyi GN. Overview of Resistance to Systemic Therapy in Patients with Breast Cancer. In: Yu D, Hung M-C, editors. Breast Cancer Chemosensitivity. New York, NY: Springer New York. 2007: 1-22.

15. Gullett NP, Ruhul Amin ARM, Bayraktar S, Pezzuto JM, Shin DM, Khuri FR, et al. Cancer Prevention With Natural Compounds. Seminars in Oncology. 2010; 37: 258-281.

16. Melo FHMd, Oliveira JS, Sartorelli VOB, Montor WR. Cancer Chemoprevention: Classic and Epigenetic Mechanisms Inhibiting Tumorigenesis. What Have We Learned So Far? Frontiers in Oncology. 2018; 8.

17. Ouhtit A, Gaur RL, Abdraboh M, Ireland SK, Rao PN, Raj SG, et al Simultaneous inhibition of cell-cycle, proliferation, survival, metastatic pathways and induction of apoptosis in breast cancer cells by a phytochemical super-cocktail: genes that underpin its mode of action. J Cancer. 2013; 4 : 703-715

18. Moiseeva EP, Manson MM. Dietary Chemopreventive Phytochemicals: Too Little or Too Much? Cancer Prevention Research. 2009; 2: 611-616.

19. Mehta RG, Murillo G, Naithani R, Peng X. Cancer Chemoprevention by Natural Products: How Far Have We Come? Pharmaceutical Research. 2010; $27:$ 950-961.

20. Chan MM, Chen R, Fong D. Targeting cancer stem cells with dietary phytochemical - Repositioned drug combinations. Cancer Letters. 2018; 433: 53-64.

21. Kawasaki BT, Hurt EM, Mistree T, Farrar WL. Targeting cancer stem cells with phytochemicals. Mol Interv. 2008; 8: 174-184.

22. Yagil R. Comparative Alternative Medicinal (CAM) Properties in Camel Milk for Treatment of Epidemic Diseases. J Agr Sci Tech. 2013; 3: 575-580.

23. Abdel Gader AGM, Alhaider AA. The unique medicinal properties of camel products: A review of the scientific evidence. Journal of Taibah University Medical Sciences. 2016; 11: 98-103.

24. Sharmanov T, Zhangabylov AK, Zhaksylykova RD. [Mechanism of the therapeutic action of whole mare's and camel's milk in chronic hepatitis]. Vopr Pitan. 1982: 17-23

25. Redwan RM, Tabll A. Camel lactoferrin markedly inhibits hepatitis C virus genotype 4 infection of human peripheral blood leukocytes. J Immunoassay Immunochem. 2007; 28: 267-277.

26. Ikeda M, Nozaki A, Sugiyama K, Tanaka T, Naganuma A, Tanaka K, et al. Characterization of antiviral activity of lactoferrin against hepatitis $\mathrm{C}$ virus infection in human cultured cells. Virus Research. 2000; 66: 51-63.

27. Sharmanov T, Kadyrova R, Salkhanov BA. [Effectiveness of peptic ulcer diet therapy using rations containing whole mare's and camel's milk]. Vopr Pitan. 1981: $10-14$

28. Romli F, Abu N, Khorshid FA, Syed Najmuddin SUF, Keong YS, Mohamad NE, et al. The Growth Inhibitory Potential and Antimetastatic Effect of Came Urine on Breast Cancer Cells in Vitro and in Vivo. Integr Cancer Ther. 2017; 16: $540-555$
29. Korashy HM, Maayah ZH, Abd-Allah AR, El-Kadi AO, Alhaider AA. Came milk triggers apoptotic signaling pathways in human hepatoma HepG2 and breast cancer MCF7 cell lines through transcriptional mechanism. Journal of biomedicine \& biotechnology. 2012; 2012: 593195.

30. Korish AA, Abdel Gader AGM, Alhaider AA. Camel milk ameliorates the coagulopathy in streptozotocin diabetic rat model. International Journal of Dairy Technology. 2015; 68: 79-87.

31. El Agamy ESI, Ruppanner R, Ismail A, Champagne CP, Assaf R. Antibacteria and antiviral activity of camel milk protective proteins. Journal of Dairy Research. 1992; 59: 169-175.

32. Alhaidar A, Abdel Gader AG, Mousa SA. The antiplatelet activity of camel urine. J Altern Complement Med. 2011; 17: 803-808.

33. Khedr A, Khorshid F. Characterization and Determination of Major Bioactive Acids in Camel Urine Using Gas Chromatography Mass-spectrometry. Indian J Pharm Sci. 2016; 78: 680-687

34. Al-Awadi A, Al-Judaibi A. Effects of Heating and Storage on the Antifungal Activity of Camel Urine. Clin Microbiol. 2014; 3: 179.

35. Alhaider AA, El Gendy MA, Korashy HM, El-Kadi AO. Camel urine inhibits the cytochrome P450 1a1 gene expression through an AhR-dependent mechanism in Hepa 1c1c7 cell line. Journal of ethnopharmacology. 2011; 133: 184-190.

36. Sawaya WN, Khalil JK, Al-Shalhat A, Al-Mohammad H. Chemical Composition and Nutritional Quality of Camel Milk. Journal of Food Science. 1984; 49: 744-747.

37. Gul W, Farooq N, Anees D, Khan U, Rehan F. Camel Milk: A Boon to Mankind. International Journal of Research Studies in Biosciences. 2015; 3: 23-29.

38. Ahamad SR, Alhaider AQ, Raish M, Shakeel F. Metabolomic and elemental analysis of camel and bovine urine by GC-MS and ICP-MS. Saudi Journal of Biological Sciences. 2017; 24: 23-29.

39. Gupta I, Ouhtit A, Al-Ajmi A, Rizvi SGA, Al-Riyami H, Al-Riyami M, et al. BRIP1 overexpression is correlated with clinical features and survival outcome of luminal breast cancer subtypes. Endocr Connect. 2018; 7: 65-77.

40. Abuelgasim KA, Alsharhan Y, Alenzi T, Alhazzani A, Ali YZ, Jazieh AR. The use of complementary and alternative medicine by patients with cancer: a cross-sectional survey in Saudi Arabia. BMC Complement Altern Med. 2018; 18: 88

41. Hasson SS, Al-Busaidi JZ, Al-Qarni ZA, Rajapakse S, Al-Bahlani S, Idris MA et al. In Vitro Apoptosis Triggering in the BT-474 Human Breast Cancer Cell Line by Lyophilised Camel's Milk. Asian Pac J Cancer Prev. 2015; 16: 66516661.

42. Nukumi N, Iwamori T, Kano K, Naito K, Tojo H. Whey Acidic Protein (WAP) regulates the proliferation of mammary epithelial cells by preventing serine protease from degrading laminin. Journal of cellular physiology. 2007; 213 : 793-800.

43. Hessin A, Hegazy R, Hassan A, Yassin N, Kenawy S. Lactoferrin Enhanced Apoptosis and Protected Against Thioacetamide-Induced Liver Fibrosis in Rats. Open access Macedonian journal of medical sciences. 2015; 3: 195201.

44. Alexander $\mathrm{DB}$, ligo $\mathrm{M}$, Yamauchi $\mathrm{K}$, Suzui $\mathrm{M}$, Tsuda $\mathrm{H}$. Lactoferrin: an alternative view of its role in human biological fluids. Biochemistry and cell biology = Biochimie et biologie cellulaire. 2012; 90: 279-306

45. Kanwar JR, Roy K, Patel Y, Zhou SF, Singh MR, Singh D, et al. Multifunctional iron bound lactoferrin and nanomedicinal approaches to enhance its bioactive functions. Molecules. 2015; 20: 9703-9731.

46. Korashy HM, El Gendy MA, Alhaider AA, El-Kadi AO. Camel milk modulates the expression of aryl hydrocarbon receptor-regulated genes, Cyp1a1, Nqo1, and Gsta1, in murine hepatoma Hepa 1c1c7 cells. Journal of biomedicine \& biotechnology. 2012; 2012: 782642.

47. Hallgren O, Aits S, Brest P, Gustafsson L, Mossberg AK, Wullt B, et al. Apoptosis and tumor cell death in response to HAMLET (human alphalactalbumin made lethal to tumor cells). Advances in experimental medicine and biology. 2008; 606: 217-240. 
48. Gustafsson L, Aits S, Onnerfjord P, Trulsson M, Storm P, Svanborg C Changes in proteasome structure and function caused by HAMLET in tumor cells. PloS one. 2009; 4: e5229.

49. Krishnankutty R, Iskandarani A, Therachiyil L, Uddin S, Azizi F, Kulinski M et al. Anticancer Activity of Camel Milk via Induction of Autophagic Death in Human Colorectal and Breast Cancer Cells. Asian Pac J Cancer Prev. 2018 19: 3501-3509.

50. Badawy AA, El-Magd MA, AISadrah SA. Therapeutic Effect of Camel Milk and Its Exosomes on MCF7 Cells in Vitro and In Vivo. Integr Cancer Ther. 2018; 17 : 1235-1246.

51. Alghamdi Z, Khorshid K. Cytotoxicity of the urine of different camel breeds on the proliferation of lung cancer cells, A549. J Natur Sci Res. 2012; 2: 9-16.

52. Al-Yousef N, Gaafar A, Al-Otaibi B, Al-Jammaz I, Al-Hussein K, Aboussekhra A. Camel urine components display anti-cancer properties in vitro. Journal of ethnopharmacology. 2012; 143: 819-825.

53. Ahamad SR, Alhaider AQ, Raish M, Shakeel F. Metabolomic and elemental analysis of camel and bovine urine by GC-MS and ICP-MS. Saudi J Biol Sci. 2017; 24: 23-29
54. Rosenthal GA, Nkomo $P$. The natural abundance of L-canavanine, an active anticancer agent, in alfalfa, medicago sativa (L.). Pharm Biol. 2000; 38: 1-6.

55. Vynnytska-Myronovska B, Bobak Y, Garbe Y, Dittfeld C, Stasyk O, KunzSchughart LA. Single amino acid arginine starvation efficiently sensitizes cancer cells to canavanine treatment and irradiation. Int J Cancer. 2012; 130: 2164-2175.

56. Vynnytska BO, Mayevska OM, Kurlishchuk YV, Bobak YP, Stasyk OV. Canavanine augments proapoptotic effects of arginine deprivation in cultured human cancer cells. Anticancer Drugs. 2011; 22: 148-157.

57. Delou JMA, Biasoli D, Borges HL. The Complex Link between Apoptosis and Autophagy: a Promising New Role for RB. Anais da Academia Brasileira de Ciências. 2016; 88: 2257-2275.

58. Almahdy O, El-Fakharany EM, El-Dabaa E, Ng TB, Redwan EM. Examination of the activity of camel milk casein against hepatitis C virus (genotype-4a) and its apoptotic potential in hepatoma and hela cell lines. Hepat Mon. 2011 11: 724-730. 